Roundtable Discussion

\title{
STUDYING CANADA IN CUBA, STUDYING CUBA IN CANADA. A ROUNDTABLE DISCUSSION
}

\section{BY EMILY KIRK}

\begin{abstract}
Canada and Cuba have a long historical relationship, in governmental and non-governmental realms alike. While hundreds of Canadian students take part in educational exchanges from a variety of Canadian universities, Canadian/Cuban scholarly ties are not as strong as they are in the US or even the UK. There are a handful of internationally recognized Cuba scholars who have been working in Canada for some decades, among them John M. Kirk, Hal Klepak and Keith Ellis. Cuban scholarship in Canada is still notably scant and it cannot really be classified in generational terms. However, it is clear that the work of these senior scholars is bearing fruit, as other scholars located in Canada are increasingly working in Cuban Studies, in both teaching and research.

A few of these scholars came together recently to discuss their experiences. This isn't an exhaustive or representative group. ${ }^{1}$ The participants in this roundtable conversation include those trained as Cubanists, trained in other fields but with more recent research and/or teaching ties to Cuba, and a Cuban educated in Canada. We came together to discuss what we see as the state of the field in Cuban/Canadian studies today and in the future.
\end{abstract}

The participants are:

Emily Kirk, Postdoctoral Fellow, Dalhousie University

Karen Dubinsky, Professor of Global Development Studies/History, Queen's University

Cynthia Wright, Assistant Professor, School of Gender, Sexuality and Women's Studies, York University

Zaira Zarza, Postdoctoral Fellow, University of Alberta.

Sandra Rein, Associate Professor of Political Science, University of Alberta

\section{Keywords}

Cuba; Canada; International Relations; Education 


\section{Personal introduction, how did you get involved in Cuba related scholarship, research and/or teaching?}

EK: My experience with Cuba has been unusual. Because my father, John M. Kirk, researched Cuba throughout his academic career, and was involved with various diplomatic projects, the island's history and ideology have been a significant part of my life since I was a child. My first trip to Cuba was when I was 7 years old, and since I was a teenager I've visited the island roughly once a year. I grew-up with a wide variety of Cubans frequently visiting our home in Halifax for dinner, including academics, fishermen, diplomats, artists, and musicians. I studied at the University of Havana as an undergraduate, and have conducted research for various projects focusing on Cuba, mainly related to healthcare and sexual diversity. I have also been teaching about Cuban history and international relations for the last six years. It is fair to say that so far, my professional career has been firmly rooted in the study of Cuba.

KD: In 1978 I joined the Canadian delegation to the World Festival of Youth and Students in Havana, attended by almost 20,000 people from around the world. I was a 21-year-old student activist who wanted to change the world; this seemed like the right place to be. The streets were lined with billboards with Fidel Castro's smiling face captioned: Joven del mundo Cuba es tu casa/ Youth of the world, Cuba is your home. I suppose I took him at his word. I was young and politically naïve, but that experience was foundational. It taught me something I still cherish, about the richness of cultural and affective ties across boundaries. Forty years later I recognize my experience in what post-colonial theorist Leela Gandhi has termed the history of affective communities. (Gandhi, 2006) Friendship, in a word.

I continued as a typical Varadero-vacationing Canadian tourist for some years after that. I approached Cuba as a research site later, when I started working on a project regarding transnational child adoption and migration conflicts. I spent several months in Havana in 2004 learning about Operation Peter Pan, how the US manipulated post-1959 anxieties by encouraging the migration of 14,000 unaccompanied children from Cuba to the US to wait things out. (de los Angeles Torres 2004, Dubinsky 2010)

I'm trained as a Canadian historian; I'm not a Cubanist. But I have now done several research projects about the place: a co-edited book on beloved Cuban musician Carlos Varela, and I wrote a book on daily life and culture in Havana. With John M. Kirk, I have begun a new project on Cuban/Canadian ties in the non-governmental realm: Canadian development projects, educational and cultural ties, Cuban musicians in Canada, sport and medical ties, etc.

For ten years I've worked with others at Queen's University teaching a semester long Cuban culture and society course which begins in Canada and ends with a two week 
field school in Havana, where we are taught by Cuban instructors as well as practitioners such as curators, musicians and filmmakers. The course is part of an exchange agreement with the University of Havana that also allows us to invite Cuban scholars, musicians and filmmakers to Queen's annually.

CW: Nothing in my academic training prepared me for work on Latin America, Cuba, or Canada and Cuba. Nor am I old enough to be of the political generation for whom the Cuban Revolution was a major turning point, but I have learned much over the years from that generation. I began work on Canada-Cuba well after I had finished my doctoral work and published in other research fields. Once I became politically active in Toronto in the 1970s and 1980s, I was exposed to the oral political history of the Left. Margaret Randall came to town in that era to talk about women in Nicaragua, and read a brief testimony from Haydée Santamaría about Moncada. Many of these stories stayed in my mind, so sometimes I like to say that, like a lot of people of my generation, I got to Cuba via Central America. The strong Nicaraguan solidarity movement in parts of Canada brought veterans of the Cuba solidarity movement into view. It was not until I went to Nicaragua in the 1990s that I had any clue that there had been a Fair Play for Cuba network in Canada, a subject that later became the focus of my research. My first visit to Cuba was in December 1993-January 1994 during one of the direst moments in the Special Period. I returned two or three years later with a delegation of US academics, all part of the Conference of North American and Cuban Philosophers and Social Scientists. This was my first encounter with academic diplomacy.

I do not see myself as a specialist on Cuba, but I am interested in reconceptualising aspects of international history from below by exploring non-state diplomacies of various kinds, including the early solidarity work of Fair Play. I do not currently teach a dedicated course on Cuba, although I want to develop one. For now, I incorporate literature on Cuba into some of my existing courses.

ZZ: I am an Art Historian by training with a passion for cinema and foreign languages. I learned English through music and film as a child in Havana. Working as an interpreter connected me to Canada for the first time in 2007. I interpreted for the Queen's course in Havana students for six years while I gained professional experience in Cuba and finished my Master's degree. In 2011, I decided to apply to do a PhD in the new Cultural Studies graduate program at Queen's. I had become familiar with students and professors throughout the years, and it sounded right as a transnational learning experience. I have been living between Cuba and Canada ever since.

I only started seriously researching Cuba during my PhD. I was living far from home for the first time and my interests started to shift towards autobiographical cinema, particularly the films made by young Cuban filmmakers in the diaspora. Not unlike me, 
they were first-generation migrants going through similar processes of adjustment and integration. We had all spent our childhood in Cuba during the Special Period. While at Queen's, I continued to work in the Cuba course as an interpreter and co-instructor. I have learned more about my country with my Canadian students in the field than I ever would have been able to learn from reading a thousand books. Cultural translation and extensive field work on the island have become an inextricable part of my scholarship. I am currently a Killam postdoctoral fellow at the University of Alberta, and I am a teacher, researcher, and cultural promoter. I am committed to and enjoy working across borders. I owe this to becoming an international student: one of the best, most challenging professional and personal decisions I have ever made.

SR: My first trip to Cuba was the same as many Canadians, as a tourist to Varadero in 1999. By this time, I had undertaken graduate studies with a general interest in Latin America but was in no way a "Latin Americanist". But, I was fortunate because my graduate supervisor was Dr. Fred Judson, a noted Latin Americanist and specialist on the Cuban military. (Judson 1984) So, I entered Cuba for the first time sympathetic to the goals of the Revolution, but also somewhat informed about the uneven distribution of the goods of that Revolution. Moreover, although it was eight years after the declaration of the Special Period the more general scarcities that were acutely felt by Cubans were still apparent even to tourists. This complex picture of a revolution in permanence, the obvious cult of Che, and the contradictions of tourist plenty among significant local scarcities, piqued my interest and I returned to the island several times between 1999 and 2003; although, never for exclusively research or scholarly reasons.

In 2008, I was approached by Dr. Roger Milbrandt who was the coordinator of a Cuban semester-long study abroad program at the Augustana Campus of the University of Alberta to take over the program. Although I was not a Latin Americanist, he was confident that I could contribute to the student experience and grow an even deeper relationship with our partner university, Universidad de Oriente. Since 2008, I have lived for extended periods in Santiago de Cuba, Cuba and worked with more than 120 Canadian undergraduate students and around 100 Cuban undergrads over 5 semesters.

\section{What do you see as some of the challenges and rewards for Canadian-based students who participate in study-in-Cuba programs? And also, for Cuban students studying in Canada?}

EK Cuba has a notably rich history, involving struggles of indigenous communities, colonialism, a mono-crop economy, as well as deep-rooted racial and ideological challenges, and an intense sense of nationalism. For a Canadian student, this translates into a very rewarding - albeit at times challenging-experience. 
One of the most significant rewards for Canadian students studying in Cuba is the opportunity to see and experience a completely different environment, and the subsequent impact that experience has on an individual. When immersed in dramatically different surroundings, students are often forced to re-examine previously held beliefs and understandings. Indeed, study-in-Cuba programs encourage students to think critically and broaden their worldviews.

In addition, from an International Development specialist's perspective, studying in Cuba is ideal to see development theories and approaches (Import Substitution Industrialization, agricultural diversification, debt repayment, internationalism, etc.) in action. The results of the various approaches employed throughout the stages of Cuban history, particularly revolutionary history, are evident throughout the island. It is uncommon for these complex theories to be so visually apparent, providing daily examples of the complicated ideas that most students have only read about. This includes the free healthcare and education systems, architecture, housing, available food and cultural representations, such as music and art. In other words, for students, the complexity of Cuban development brings theories from books into everyday experiences.

KD: Our students are well prepared when we arrive, as we have over a dozen three-hour classes with them in Canada. But most of them have grown up with a lifetime of Canadian stereotypes about Cuba, the Caribbean, and the Global South in general.

There are some very good studies about the political and ethical issues associated with study abroad programs. Are such courses merely "voluntourism" or "edutainment?" To what extent to educational excursions, particularly to the Global South, heighten, diminish or simply avoid complicated questions of global inequalities? (Tiessen and Huish 2014). I always remember the reaction from a Development Studies student when she learned of the 1961 Cuban Literacy Campaign. "That's the kind of work I want to do abroad when I graduate; you mean Cubans did it themselves?" To me that line alone speaks volumes about the level of awareness of the student in our First World classes today.

Experiential learning takes place in the classroom but of course outside it as well. After class, our students roam the city pretty much as they like; they make friends with University of Havana students, they hang out on the Malecón. Havana remains a relatively safe place to be, for residents and visitors alike. What our students learn informally forms a huge part of the course conversation, especially when it contrasts with what they hear or read in class. In the Internet age - despite its problems in Cuba - these friendships continue. Several students have returned to Havana with their families, to show them the city and to meet up with the friends they made through the course.

The reason our course is organized around social and cultural themes is because that is where so many of the interesting conversations take place in Cuba. However, most of our students are not Spanish speakers, so sadly they miss many of the nuances and 
cultural subtleties. Of course, there are subtitles, translators, and interpreters. But in Havana they realize their limitations in terms of understanding the culture without language skills, which is actually a great lesson for English-speaking First World students to recognize. It also spurs some of them on to language instruction, another good lesson.

Some female students have problems with Havana street culture. We speak and read a lot about differing sexual cultures in the world. But sometimes such nuances are lost, and without much Spanish, many have trouble distinguishing between a piropo (compliment) grosero (lewd remark) or even knowing how to interpret a look. (Lundgren 2013) It provides for some great conversation - and of course some stress as well - but it too can be an opportunity for students to reflect on their own world. Queen's is a whitedominated institution, but some years our course attracts what is (for Queen's) a relatively diverse student group. One year one of the black students addressed her white classmates who had been speaking quite passionately about the cat-calling they were experiencing on Havana's streets. "I'm sorry you are feeling threatened by this," she said, "but I want you to understand that here I feel more comfortable than I do on the streets of Kingston. Havana is not the exclusive preserve of white people."

As Zaira Zarza explains here, Queen's has hosted a few Cuban graduate students in the past few years. However, I think something important has been lost in Canadian/Cuban educational ties: reciprocity. In the 1970s the Canadian government development agency CIDA sponsored a program to help Cuba boost its engineering educational capacity. As part of that project, over 70 Cuban students and professors came to study in Canadian universities. Decades later, a 2012 study sponsored by the Canadian embassy in Havana noted that merely 34 Cuban students had received Canadian funds to study in Canada since 2000; that's only about 2 per year over the past twenty years. (Betancourt, 2014)

CW: The other roundtable participants have rich experience in this area and I have learned much from them. In particular, spending time with the Queen's University Cuban Culture and Society course was an enormous pleasure from which I learned a great deal about, among other things, ways of building strong personal, intellectual and collaborative work relationships with Cuban academics, cultural producers and teachers of all kinds. I strongly encourage everyone doing such work to teach and write about it, and also to think about it in the broader context of academic diplomacies. There is very little scholarly literature, for example on Canadian university courses in Cuba. Karen Dubinsky's recent contribution, "Taking Generation NGO to Cuba: Reflections of a Teacher," forms an exception (Dubinsky 2018). US-based academics - Sheryl Lutjens comes to mind - have written thoughtfully about Cuba-US academic exchange. (Lutjens 2017) On the Cuban side, Milagros Martínez Reinosa has written on the problems and 
potentials of Cuba-US academic collaboration, but as far as I am aware no equivalent body of work exists on Cuba-Canada academic collaboration from Cuban and CubanCanadian perspectives (Martínez 2017).

ZZ: The students' knowledge grows exponentially when they are immersed in the culture they are learning about in class. Global North-Global South relations, at the core of scholarly debates in Development Studies, are particularly interesting in these crosscultural experiences. Although temporarily, Canadian students that engage in studyabroad programs in Cuba get to be a component of the island's social dynamics and experience some everyday-life events in that specific context. In Cuba, both Canadian students and teachers develop relationships with their local peers, and are able to put their own ideas about gender, race, and nationalism in perspective. When they leave Cuba, they are more prepared to celebrate and question Canada.

The biggest challenge is getting out of one's comfort zone. But that is also the best part of the process. Recognizing our privileges, and being mindful of the complexities of a country so different from theirs is invaluable. The students are aware of their position as outsiders: they stay in hotels, have access to the latest technology unavailable in Cuba, and own the hard currency that their Cuban colleagues can't access. But, as diasporic filmmaker Trinh T. Minh-ha puts it: "[e]very voyage can be said to involve a re-siting of boundaries." (Minh-ha 1994) The diversity of ideas and points of view, and the affective experiences that the students have to process during their trip, I think make them understand how ultimately cultural difference is not something to overcome but to embrace.

The same phenomenon happens in reverse. I had read some of it previously in Cuba, but when I arrived in Canada, the work of Gayatri Spivak, Arjun Appadurai, Stuart Hall, and other postcolonial writers writing from the Global North became clearer. Their experiences taught me a lot about myself. Raka Shome, in particular, has worked recurrently on the decolonization of academic knowledge. I understood so much of my early discomfort when I read her "Post-Colonial Reflections on the 'Internationalization' of Cultural Studies." Shome noted how she was a sort of elephant in the room in the North American and British academic contexts. Not unlike many of those scholars, I also remember feeling a sort of diasporic guilt, caused by my new financial and technological privilege. I had constant Internet, I was in a full-time academic program, food insecurity was not a problem, I was more mobile than ever before. That was an advantageous position from which to speak when compared to my colleagues back home, and I grew extremely aware of that reality during my first few years of displacement.

SR: Let me begin with challenges. I suspect that many of these would be similar for any semester-long program that is running in parts of the world that do not have the same 
standard of living to which Canadians are generally accustomed and the primary language is not English.

Canadians are challenged by the lack of easy, fast or affordable Internet access. Santiago does not have the Internet access of Havana - which itself is not very good. While this environment has improved in many ways, the requirement to access the Internet in open, public spaces in Santiago exposes students to certain vulnerabilities, such as having expensive electronic devices like tablets or laptops out in public view. While Cuba is generally safe, foreigners can be marked for theft and it does restrict easy access. Universidad de Oriente attempts to provide email access for Canadian students; however, this is less reliable than other public avenues. One of the solutions that Canadians often employ is to use the Internet at the international hotel. This is expensive and also removes the Canadians from general contact with the Santiago community and returns them to a more "reified" international space. While sometimes necessary, it is not ideal when seeking cross-cultural experience and community engagement.

Secondly, language and cultural barriers are certainly challenging but they are also one of the key reasons for undertaking the program in the first place. Related to this challenge, though, are also the significant differences of studying at a Cuban university. Classroom interaction is often structured differently in Canada and the majority of classroom content in Cuba is delivered orally.

To my mind, it is the rewards that far out-weigh the challenges of living and studying in Santiago de Cuba. Although they may appear obvious, these include experiencing a cultural environment that is significantly different than Canada. Santiago de Cuba in particular has an Afro-Cuban culture that is less apparent in other parts of Cuba. It is also important to note the value of engaging in a historical context that is rich in revolutionary and anti-colonial tradition. This translates to living in a space that occupies what was once known as the Second or Third World but today is a complex mix of a transitioning economy, entrepreneurial excess, failing infrastructure and unclear political succession. Finally, a significant reward is building strong and lasting relationships with Cubans, as members of families and friendship networks.

We have not been able to have Cuban undergraduate students join us at the University of Alberta in anything like an exchange. The Canadian government at one time offered professional development scholarships to Cuban academics who wished to undertake a project in Canada. This was heavily biased toward central and Eastern Canada as the awards were not sufficient for Cubans to reach the western part of Canada. Yet these programs were mostly discontinued under the Harper government and federal support for Canadian Studies in Cuba has been significantly restricted as a result. We have been able to host for brief periods Cuban professors and would hope to see new funding opportunities in the future. Certainly, a long-term goal (and dream) would be to transition our Cuba program into (at least in part) an exchange program that would host undergraduate Cubans at the University of Alberta. 


\section{Is there anything distinctly different about working on Cuba in or from Canada? What does it mean to study, write and teach about Cuba in a country such as Canada, that has a popular but arguably one-dimensional, touristic understanding of the place?}

EK I have worked on Cuba from both England and Canada. Working from England was a very positive experience, particularly working through the Centre for Research on Cuba at the University of Nottingham, which is well known in Havana. Nonetheless, the difference of working from Canada is distinctive. I believe this is mainly the result of two factors. The first, that Canada and Cuba have traditionally maintained positive relations. Canada, along with Mexico, were the only two OAS countries that maintained diplomatic relations with Cuba after the US imposed an economic embargo and broke diplomatic relations in the early 1960s. (Kirk 1997, 42-43) Throughout the decades (and despite a slight cooling of relations during the Harper years), the two countries have continued to develop strong economic and cultural ties. Secondly, Canadian tourists are commonplace throughout Cuba (over 1.3 million a year) and make up $40 \%$ of all tourists to the island. This consistent contact with Canadians above other nationalities has undoubtedly contributed to the positive and respectful view of Canadians held by Cubans. For these two primary reasons, there seems to be an inherent respect for Canadians working in or on Cuba. Revolutionary Cuba has a long memory and it is evident that Canada's loyalty has not been forgotten. This translates into a largely positive working relationship between professionals in both countries, respectively.

When attempting to teach or discuss Cuba in a balanced way, challenges can and do arise. It feels at times that there are two primary groups. The first consists of a solidarity perspective of those (friends of and/or academics working on Cuba) who are fascinated by the island's tremendous successes in healthcare and education, and are inspired by the Revolution's survival despite the US's aggressive economic embargo. The second group consists of those who fully believe in the media's representation of Cuba as a dangerous communist country, headed by the Castro dictators. This was evident, for example, following Fidel Castro's death, where the most common descriptions of the former president in the media revolved around terms such as "tyrant", "dictator", "repressive", and "abuses of human rights" (Milke 2016; Associated Press 2016; Reuters 2016). Both groups can pose diverse but significant challenges when discussing Cuba. Rather than lecturing, scolding, or praising, my strategy has always been to ask questions such as "why you do think that is?" or "why do you feel that way?" Sometimes, although not always, opinions change and a more balanced understanding is achieved. 
KD: I think it matters a great deal - for anyone in Canada researching or teaching Cuban studies - that Canadians compose the largest single group of visitors annually. The perceptions and relationships formed between nations through tourism are a really significant but I think barely understood part of international relations. Some commentators - academics and others - write as though tourism is wholly a North American or European fantasy, and thus that resort areas like Varadero for example are not the "real" Cuba. I think that's too simple. I encourage students to think about the relationships they see in the tourist industry, what kind of meaning and knowledge are produced in tourist encounters? Since so many of our students have had a Cuban tourist experience with their parents before they take our course, we find lots to talk about in terms of the differences between resort Cuba and what they are experiencing in Havana. Both are "real," or perhaps from the perspective of a visitor "unreal" in different ways.

There's a story I like that encapsulates something about the Cuban/Canadian relationship. An Afro Cuban friend in Toronto has a strategy for dealing with police on the multiple occasions he is needlessly stopped on the streets. He immediately summons his best Cuban English accent. The police ask him where he's from, he replies Cuba. "Ah, Cuba," is the usual reply, "I love Varadero." Usually that ends the story. This doesn't absolve the racism of Canadian police, of course, but there is something weirdly, uniquely Cuban/Canadian about this.

At the same time Donald Trump began to undo the US/Cuba links reopened in the Obama era, the agreement that structures the relationship between Queen's University and the University of Havana came up for renewal. What a lesson this was on the benefits of working on Cuba from Canada: I observed on-line conversations from Cuban Studies colleagues in the US bemoaning that their universities had cut their Cuban exchange student visits the same week I met with three different levels of administrators at my university, all of them eager to renew our Cuba ties.

CW: Off-island academic knowledge production about Cuba is still dominated by US scholars (including various generations of the Cuban-Americans) with diverse political orientations in relation to Cuba. In international conferences such as the Latin American Studies Association (LASA), dialogues between academics located in Cuba and those in the US have been very important politically and intellectually, and have often continued regardless of the tensions between the two states. The dominance of US scholars has historically also favoured a particular kind of US scholarship focused on hostilities between Cuba and the US. That scholarly theme is likely to continue for some time. At the same time, this structural dominance has also provided an interesting opening for some Canadian and Cuban scholars to explore the dimensions of the Cuba-Canada relationship, and to try and account for why one of the US's greatest allies has pursued a 
different path in relation to Cuba, at least in regards to maintaining diplomatic relationships since 1959. It has also led some scholars to pursue the theme of the diplomacies practiced by non-state actors and intermediaries of various kinds. This research path also opens up some possibilities in Canada for comparative dialogue with the Mexican scholarship.

While US scholarship dominates the field, the work of some fine British scholars of Cuba has received more attention in recent years and of course there are senior scholars of Cuba in Canada who have cleared a path for many of us by publishing in key areas such as the military and Cuba's medical internationalism. (Kirk 2015; Klepak 2005) The 2009 conference at Queen's University in Kingston, Ontario that marked the fiftieth anniversary of the Cuban Revolution was notable for the fact that it brought together scholars from a broad range of national contexts and it did not rotate on the US-Cuba exchange, important as that is.

US-based scholars in general are far better resourced, in Cuban Studies as in other areas. There are a number of Cuban Studies programs and resource centres in US universities, and regular Cuba-dedicated conferences are offered. On the other hand, because of legal restrictions on the US side, it remains complicated for US nationals to travel to Cuba to carry out research and fieldwork. This in turn structures the kind of work that gets done and the topics that are addressed. In this regard, scholars from Canada, if they have financial resources, are far better off since they do not have to negotiate a travel minefield. What we need to work on is more financial pathways for Cuban scholars to carry out research in Canada. There are some rich opportunities for collaborative work between scholars located in Cuba and Canada that need to be explored. Greater access to email (difficult as it remains in Cuba) and social media tools offer us some possibilities that were not there before.

ZZ: From the teacher's perspective, I think that although inaccurate and tamed by the superficiality of beach tourism, Canadian students have a positive image of Cuba overall. Most of them have been there with their families in resorts and so they take university courses on Cuba hoping to return and learn more deeply about the island's culture and society. I think that would not be the case in an American classroom, for the obvious reasons of restriction on US citizens to travel to Cuba and decades-long history of hostility between both nations.

From a researcher's point of view, my experience has been twofold. I think I've had a pretty smooth road along the way in Canada to develop my creation-based scholarship on Cuban diasporic cinemas. Due to Cuba's highly-politicized exilic history in the United States, I am sure I would have encountered many more challenges there. This circumstance hasn't made my commentary on Cuban contemporary culture and politics less acute. It has however made me aware of the lack of interest in Latinx cultures in Canada when compared to the United States. I always remember my mixed feelings 
when I first attended Toronto's Caribana festival in Toronto: one of the most important events to celebrate Caribbeanness in the city. I was really hoping to see a more diverse representation of the Caribbean, and not just of the Anglophone countries in the region. Of course, we live in a post-colonial world, and not even Caribana can escape that.

Overall it is actually very rewarding to teach about Cuba from Canada. Many of our students start with a basic knowledge and we watch this noticeably grow and expand. We see their transformations after they have spent time learning in Havana. Everything doesn't run smoothly all the time, of course. I recently had an unforgettable encounter that reminded me how one can also occasionally fail as a teacher. I found myself at an event with a former student a couple years after I taught her in Canada. We caught up briefly and I explained how the previous winter I had been in Cuba conducting research related to my postdoc. She responded with an ironic tone: "Sure, yeah... 'research," and used her fingers to sign aerial quotation marks. I had worked really hard that winter, and her level of sarcasm about scholarly knowledge production and hard academic work in Cuba was just shocking to me. I still haven't processed how to implement new teaching tools to prevent such assumptions in the future. But I can only thank my former student for reminding me that I should do so much more.

SR: Communicating with colleagues in Santiago de Cuba is more difficult than working with colleagues in any other country with which I have experience, given the lack of Internet access. However, I think the question points to more than just the material. I write very little about Cuba in comparison to my other research areas. This is not for lack of interest or observation/opinion but more out of a respect for those with whom I work closely in Santiago to provide our undergraduate program. My colleagues and Cuban friends are not research objects and I would not want them to ever feel as such. Moreover, there are real sensitivities around what is researched and published about Cuba that can make vulnerable contacts in the country. Finally, I am cautious about expanding my personal experience to a more authoritative commentary about Cuba or Cubans more generally. I think I would exercise caution with regard to any group or incountry experience but I think the Cuban context is also further complicated by a desire to be supportive of Cuba's project (or parts of it) in the face of the US Embargo and antiCuban politics.

I sometimes find that I spend a great deal of time combatting false stereotypes and correcting misunderstandings. Even in academic settings, I regularly encounter people "explaining" what is legal in Cuba, for example. Or, in an opposite direction, naïve celebrations of the Cuban Revolution that ignore the very idea that Cuba is populated by living people with a variety of experiences, opinions and politics. That said, I also recognize that my own understandings are highly mediated as a result of working largely within a Cuban university and also standing outside Cuban culture and language. So, to 
better answer the question, what it means is that one is always attentive to both the stereotypes and how one's own portrayal and research may also misrepresent or exaggerate certain aspects of Cuban experience. In essence, I find it a delicate balancing act and prefer to try to find ways for Cubans to represent their own experiences, research, and politics rather than standing in their place. With tight resources and restricted opportunities, this is a difficult "balancing act", indeed.

\section{Is Cuban exceptionalism real? Is there something fundamentally different about studying Cuba?}

EK: For Cubanists there certainly is. Perhaps for the non-Cubanist, that is not always the case. In my experience, there are two main reasons for this. First, the view of Cuban 'exceptionalism' is compounded because working on Cuba is very difficult, and arguably more challenging in terms of being awarded research grants and visas than for other Latin American countries. Also carrying out research there is very difficult. It can also be more challenging to publish work on Cuba, as many reviewers hold biases surrounding revolutionary Cuba. When writing on Haiti or Brazil, for example, I'm never asked if I'm a communist. Either intentional or not, the inherent difficulties of working as a Cubanist often mean that Cuba is understood differently than other countries.

Second, the ongoing difficulties as a result of the US embargo and the enduring "David vs. Goliath" story have significantly contributed to the understanding of Cuban exceptionalism. Cubans, since the end of the War of Independence in 1898, have continued to refer to the island's extremely strong sense of nationalism to achieve independence from the United States. This sentiment was further compounded at the beginning of the Revolution in 1959, and particularly after 1961, as Cuba and the revolutionary leadership survived despite significant efforts orchestrated by the United States government. This ongoing and dramatic story has made Cuba an exception within Latin America. Despite many liberation movements and rebellions, no other country has maintained the same sweeping revolutionary values and sense of nationalism for over a century. In sum, it is perhaps fair to say that stories of the underprivileged and undervalued winning (or at least not losing) against what is viewed by many as a hegemonic power, will always be considered 'exceptional'.

KD: I echo Emily Kirk here: there is often a simple and easy presumption by many that people who research or teach about Cuba fall lockstep into line with the policies and official discourses of the Cuban government. That's as insulting to the researcher as it is to assume that all Cubans resident in Cuba speak with the same voice. I don't think people make that assumption about people who study most other countries. 
There are obvious examples of exceptionalism in Cuba's past and present: the US economic blockade, the safety of its streets, and the relative scarcity of a consumer culture. Our students sometimes even romanticize the Internet scarcity. After a few days without constant screen access they start making jokey but serious comments about how they are interacting more with each other, they are sleeping better, remembering their dreams etc. There are exceptional features of daily life in Cuba, particularly compared to the rest of Latin America.

CW: In a 1961 speech, Che cautioned against reading Cuba's revolutionary triumph through the lens of "exceptionalism" and instead pointed to the ways in which Cuba needed to be placed in the broader historical and political history of Latin America. He did note a small number of features of the Cuban Revolution that he saw as quite specific, but he was largely uninterested in exceptionalizing the Cuban story. Of course, subsequent Latin American political history calls on us to revise aspects of Che's claims and nothing like revolutionary Cuba would emerge elsewhere - and lots of political terror went into making sure more Cubas would not be born.

As Antoni Kapcia pointed out a number of years ago, the argument for so-called Cuban exceptionalism has more recently arisen in the context of scholarly work that tries to explain why Cuban realities don't follow certain scholarly and political predictions and paradigms. (Kapcia 2008) For example, as a lot of people have argued, Cuba does not fit the "transition" literature that attempts to explain the so-called post-socialist societies of Eastern Europe. Historically, one could argue, a lot of work from all political perspectives has struggled to explain Cuba's historical and political development in part because observers were drawing on theoretical frameworks that proved inadequate to understanding Cuban specificities. There are aspects of Cuba that are, in my view, exceptional and not easily explained through the theoretical frameworks on offer. Still other research questions could benefit from assuming non-exceptionality. Solidlyresearched comparative studies can also help us evaluate the strength of the exceptionality thesis as can more work on Cuban nationalism and internationalism.

ZZ: Cubanists have been trying to dismantle this notion for a long time. Especially younger generations of Cubans oppose that idea because being an exception separates us from the positive aspects of globalization. As islanders who have been politically isolated for decades, we are very eager to be worldly. However, it is true that some conditions in Cuba are unique, especially contrasting. These include, highly-educated professionals earning the lowest state-provided salaries in the world, a financial dual currency that complicates access to basic-need goods and multiple subsidized cultural options, and a disconnected society with some of the most well-informed citizens. In addition, Cuba has 
dysfunctional services in non-touristic governmental institutions but a developed worldlike health care system. Finally, it is a society with precarious organizational skills and a tremendous potential for creativity.

The revolutionary process and the crisis that accompanied it certainly made Cuba a different place. But today, I prefer to think that there is something fundamentally different about researching and learning everywhere, and Cuba is just another element of that dynamic.

SR: Well, the Political Scientist in me says that all places make exceptionalist claims and there is limited truth, usually, to the claim. However, I would certainly agree that Cuba is sui generis when compared to other states in the region and in a more global sense. As a state, the revolutionary government of Fidel Castro, in particular, was able to work within the aligned and non-aligned world - no small feat. Cuba was able to fund its development largely through its relationship with the USSR and to find alternative ways to preserve some of the key social gains of the Revolution when the Soviet Union fell. Moreover, Cuban society has realized levels of social solidarity that I think are quite remarkable (but are obviously under increasing strain). Now, do these things come together to make Cuba "exceptional", I suppose that a case can be made; however, I don't think exceptionalism is necessary to make Cuba a worthy place to study, to live, and to offer academic exchanges. For me, its difference is sufficient.

\section{What, if any, role should academic work play in Canada-Cuba solidarity movements?}

EK: Academic work is important for informing solidarity movements, as well as contributing to a balanced understanding. The same is true for the academic's role in informing the general public and the media. Research provides relevant data and important information that can be used by those engaged in solidarity campaigns. Nonetheless, for academics it can be difficult to balance participation in solidarity movements, as you can be perceived as being biased or no longer scholarly. Overall, for Canada-Cuba solidarity, academic research, as well as academics themselves, have been of crucial importance for solidarity movements, adding legitimacy through scholarly work, understanding, and institutional support.

KD: My research tends to be on the cultural, non-governmental realm; I do a lot of what anthropologists called Deep Hanging Out in Havana. I pay more attention to conversations in the music and film world in Cuba than I do to TV news or political speeches. I listen to a cross section of neighbours and friends in Havana who have a 
range of opinions. I'm doing the same now in Canada, as I interview Cubans about their experiences in Canada.

I have many Cuban friends. But for me capital "F" friendship, in the form of solidarity organizations officially tied to the Cuban government, covers only a slice of Cuban reality. I don't like the level of abstraction; my friends are people not states.

I also agree with Cuban historian Rafael Rojas that the paradigm of solidarity that has dominated discussions about Cuba from outside tends to "subordinate intellectual processes to concrete political alliances." (Rojas, 2016, 193) This assumes a political consensus - inside and outside Cuba - that I believe now is a fantasy.

CW: A lot of the first generation of writing on Cuba was passionately politically committed and in solidarity with the revolutionary project. Books such as C. Wright Mills' classic, Listen, Yankee, come to mind in that they were instrumental in building solidarity with Cuba and it is no accident that Tom Hayden and Ricardo Alarcón both return to Mills in their recent collaboration on Hayden's book, Listen, Yankee! Why Cuba Matters. (Mills, 1960; Hayden 2015) It would be interesting to explore the relationship between some of this earlier work and the nature of the political sympathies and affect it engendered. This question also raises for me: with what, or whom, is one working in solidarity as an academic? With the Cuban state, the post-1959 revolutionary project, Cuban people in all their diversity and complexity, with particular issues such as the Cuban 5, or what exactly? Some of the recent scholarship, by focusing on Cuba's successes in areas such as international solidarity and health, aligns with the goals of many solidarity movements in that it showcases clear successes of Cuba today. There are some scholars of Cuba who are not particularly sympathetic to the Cuban revolutionary project but who have nonetheless produced important work from which we can learn. Political neutrality when writing about Cuba is more or less impossible, as everyone knows, but whether that translates into work that is openly in solidarity, or which takes up research themes that are central for solidarity work, is another question.

Aside from an edited collection on "other diplomacies" in the Cuba-Canada relationship, my own research focuses on the story of the Canadian Fair Play for Cuba Committees, the first organization in solidarity with revolutionary Cuba. I am thinking through what solidarity with Cuba has meant historically, and to whom, and why. As David Roediger notes in a recent essay on solidarity, there is surprisingly little historical work on this keyword. (Roediger 2017). Doing that historical work is essential for rethinking the concept of solidarity itself for contemporary context.

Finally, I do think it's important for all who do work on Cuba to teach, write, and speak out about the blockade and its effects, including how it affects the conditions for academic life for Cuban intellectuals and cultural producers. 
ZZ: I understand solidarity as a horizontal relation, and knowledge mobilization is one of its key components. Learning about a place from a respectful and profound researchoriented point of view can certainly generate more engaged travellers, or "better tourists," as I heard Karen Dubinsky say once. The institutional agreement between Queen's and the University of Havana, for example, brings Cuban scholars to Canada every year. But everyone involved has always commented on the disparity of this exchange. Nearly forty students get to go to Cuba and only one Havana professor visits Queen's for two weeks to present their research on campus. However, it is always possible to push the limits of institutional attempts at reciprocity. Singer-songwriter Carlos Varela was granted an honorary degree at Queen's in 2014, and later that year he was the first world music artist to have a sold out concert at the newly-inaugurated Isabel Bader Centre for Performing Arts in Kingston. Jazz virtuoso Aldo López Gavilán also filled the Isabel during his solo piano concert in 2016 and more recently rapper Telmary Díaz returned to Kingston to perform and exchange with Queen's students as a guest artist and visiting instructor. Cuban filmmakers Heidi Hassan, Ricardo Acosta, Gloria Rolando and Daniel Díaz Torres have screened their work and conducted workshops. In 2015, I became the first Cuban $\mathrm{PhD}$ graduate in the Faculty of Arts and Sciences. There are now three more Cuban students in line to graduate from PhDs and MAs programs in the next couple of years. Although Queen's is among the least racially diverse universities in Canada, probably Kingston is one of the most Cuban cities in this country. Here's an example of how amazing projects that are born in academic environments can extend beyond campus and have a positive impact among broader communities.

SR: This is an important question and one that I think is tied at least in part to the question of exceptionalism (or Cuban assertions of exceptionalism). I think academic work has a significant role to play in regard to highlighting the damage caused by the US Embargo (that said, there is also a freedom that Cuba realized as a result of being excluded from the US orbit) and for challenging narrow and false characterizations of the Cuban state and Cuban society. However, academic work must also engage the real critiques of Cuban society and politics raised by Cuban activists, scholars and others in Cuba. Again, another difficult balancing act - negative critique can be used to support anti-Cuba rhetoric and naïve boosterism can undermine the real challenges that Cubans are facing. On balance, though, I hope that the study abroad programs we offer in Cuba can assist in realizing the responsibility to challenge oppressive power regimes in all their forms - US, Canadian, and even Cuban. So, I suppose, the key question, as many of us have mentioned here, is "in solidarity" with whom? Not an easy question to pose in the Cuban context given the historical centrality of the state in all manner of social and academic life. On a practical level, Canadian academics can practice solidarity with 
academic colleagues and students in Cuba by assisting with material resources, access to research materials, and support for graduate and post-doctoral students. Moreover, we can continue to be a strong voice for resurrecting past programs that provided funding for Cubans to pursue professional development and scholarly research outside of Cuba.

\section{Why does Cuba have noticeably more Canadian Studies infrastructure than Canada has for Cuban Studies?}

EK: In short, Canada matters to Cuba more than vice versa. The government in Havana makes it a priority for trade, diplomatic and political reasons. In addition, the Cuban government wants a base of knowledgeable specialists who can continue to develop and strengthen policy with Canada.

KD: I think all of us who teach or research Cuban studies in Canada have realized the dismal level of knowledge that exists in Canada about Cuba. Though that could perhaps be extended to the Caribbean and Latin America in general. I recently attended a Canadian Studies conference at the University of Havana and watched an appreciative audience listen to the Canadian writer Thomas King, and heard Cuban scholars give presentations on Margaret Atwood and Naomi Klein, for example. I was part of the Canadian delegation to the Feria del Libro in 2017 and observed Cuban enthusiasm for Canadian books and writers; including Atwood herself, Madeleine Thien, and many others.

I think the one-dimensional view of Cuba encouraged by both mass resort tourism and the on-going US/Cuba Cold War has limited a more complex understanding of Cuba among Canadians. I agree with what Sandra Rein says; a great deal of our job is to demystify stereotypes. It is such a paradox; huge numbers of Canadians both know and don't know the place at the same time.

CW: The history and development of academic exchange between Canada and Cuba is another area that could benefit from more scholarly research. Understanding Canada matters in Cuba because of the role that Canadian tourism plays in the economy and because of the Canadian state's close integration with US interests-while remaining relatively independent when it comes to Cuba policy. Some see the Canada-Cuba relationship as a potential model for how Cuba and the US might develop a modus vivendi despite major differences.

Cuban Studies in Canada is weak and is entirely lacking in dedicated research centres, conferences, associations, or organized networks. In general, Latin American and Caribbean Studies in many Canadian universities is not well-resourced, and Cuba may be 
marginalized in both Caribbean and Latin American curricular development. The Spanish Caribbean, in particular, does not get the attention it deserves although there are institutions such as the University of Toronto that do have courses in this field. But to examine the plus side, there are a number of universities with significant links with Cuba of various kinds. Still, Canadian students with serious graduate-level research interests in Cuba, find, as Emily Kirk's biography suggests, they have to go to the US or the UK.

ZZ: What a difficult question! I think that not unlike the situation in the tourist industry, Cuba needs the resources that higher education to foreign students can provide. Therefore, Cuba is better organized to welcome foreigners than Canada. When Cubans go north we need visas, but Canadians can do short-term student visits to the island without overwhelming paperwork or even a study permit, depending on the program. There are also many more funding opportunities for Canadian students to engage in study-abroad experiences, and not vice versa. While Cubans used to study abroad during the Soviet Union era in the 1970s and 1980s, that stopped as a result of the Special Period. Since then it has been the responsibility of Cuban students to find the international funding to complete their degrees.

SR: The obvious answer with regard to Canadian Studies in Cuba is that this was a funded program by the Canadian Federal government. It was born from fairly close ties to Cuba but also a broader mandate to promote Canadian Studies outside of Canada. This involved establishing Canadian Studies Chairs at Cuban universities and funding opportunities in and outside of Cuba. Cubans also recognize that there is value in promoting Canadian Studies when a significant portion of tourist dollars come from Canada and Canadians are regularly traveling to Cuba.

Cuba, on the other hand, certainly is worthy of study and enhanced attention in Canada, but I think it is often subsumed under broader categories (Latin American Studies) or lost in the notion of post-Soviet transition, which tends to overlook the particularities of individual states that held close ties with the USSR. With regard to Cuban Studies, I think we are only now beginning to realize the potential in understanding the Cuban state and society in a deeper way. There are lessons in social solidarity, literacy programing, health care delivery, state capitalism, and the conduct of foreign policy that should render Cuba a key state to study.

I would be remiss not to note that another reason for less attention to Cuba in Canada is in part a historical legacy of the difficulty of doing research in Cuba, often caused by the Cuban state itself. While this is understandable and justifiable even in the context of the open aggression of the US state, it has been a limiting factor that I think is slowly receding. In other words, we may now be on the cusp of expanding Cuban Studies in Canada in new and creative ways. 


\section{Do you think Cuba Studies in Canada and vice versa is likely to change in the post- Castro era?}

EK: In 2016, at the $7^{\text {th }}$ Cuban Communist Party Congress in Havana, amendments and new legislation were included in the Party's fundamental principles and new resolutions were developed. What these changes meant was that there was to be a "decentralization", or what is being referred to in the media as an "opening" (Castro Ruz 2016). In addition, since December 2014 there has been a process of what is being called "normalization" with the United States (although with Trump as president this has certainly changed). In a practical sense, what this means for educational programs, is that more international universities have been and will continue to attempt to develop new programs, creating significantly more competition for the Canadian programs.

Nonetheless, mainly as a result of the history of the Canadian programs as well as their attitudes of collaboration instead of control, it is clear that Canadian programs will continue to be successful. Canadian institutions have developed some of the most successful exchange programs with Cuban institutions, and have accomplished this by maintaining a positive relationship rooted in respect rather than dominance. These programs are likely to continue to thrive because of the strong ties already forged over the last half century.

KD: One of the things that will help to educate Canadians about Cuba is the spread of the Cuban diaspora in Canada, which now numbers approximately 20,000. That is not a lot but it is growing. Conversations with Cubans in Canada are going to help expose people to the variety of opinions and experiences that exist among Cubans, on and off the island. This should help Canadians avoid the caricatures and stereotypes that are so prevalent about Cuba. For example, I have seen audiences in Canada react really positively to the films Zaira Zarza has screened in various cities as part of her project on Cuban diasporic cinema. I remember well a comment from someone in the audience in Thunder Bay: "I expected because these were Cuban films they would be full of, you know, palm trees and dancing; I didn't expect family dramas and other stuff."

I think the extreme hostility of Trump-era policies are also going to help Canadians understand Cuba better simply because Canadians have enough of their own experience with and in Cuba to know how out of touch with reality Trump's administration is. Even if Canadian perceptions of Cuba are, as Zaira Zarza put it, tamed by the superficialities of beach tourism, very few people here would recognize the vicious caricature of Cuban realities currently emanating from officials in Trump's America. 
CW: It seems clear (as of this writing) that Raúl Castro has been devoting his final period in power to addressing the country's most intractable problems, including the relationship between the US and Cuba. Clearly, that relationship is now in reverse - as some of the more astute observers predicted around the time of the re-opening of diplomatic relations under Obama. Now that the relations between the US and Cuba are once again in retrograde, there may be renewed interest in studying the enduring Canada-Cuba diplomatic relationship, as well as the people-to-people relationships and dynamics. I would like to see those of us with interests in the field continue to push open spaces for research, teaching, exchange, and writing about Cuba. Finally, a lot of bad journalism and scholarship could not imagine Cuba surviving as revolutionary Cuba without Fidel and/or Raúl and predicted all kinds of scenarios that clearly have not come to pass. So one thing that might happen with the passing of Fidel and Castro from the political landscape is more serious scholarship that actually makes an effort to understand how Cuba is ruled, and by whom, and through what institutions and practices. British scholar Antoni Kapcia's recent book, Leadership in the Cuban Revolution (Kapcia 2014), moves us in this direction, and there is room for more.

ZZ: The worst part of the post-Castro era is that it overlaps with the Trump era. Slowly the Cuban government was giving clear signs of their willingness to gear the country towards a more global stance. The economy was developing more capitalistic structures at a minor scale, without following neoliberal rules. While Cubans hoped for more openness and more American tourism on the island, Canadians and people from other countries feared the prospective avalanche of careless tourists from the United States. But immediately after stepping inside the White House, Donald Trump announced that he was reversing Obama's foreign policy towards Cuba. He even reduced dramatically the consular staff in the newly inaugurated embassy in Havana after alleged sonic attacks to their diplomats. Cubans wishing to obtain US visas must travel to and apply from Colombia. So much for reconciliation. But if that situation actually reverses and Cuba and the United States renew links, I think Canadian scholars and tourists could do a great deal to inform American tourism in Cuba and contribute to improving the quality of Cuba-US academic exchanges.

SR: As the Cuban state undergoes significant change (in part caused by the shift in leadership but also due to exogenous changes in geopolitics) there is the potential for stronger research ties between Canada and Cuba. Moreover, it is important to understand and study HOW Cuba has undergone significant transition since 1991. It differs dramatically from other command economies, in particular, and these differences have forestalled significant social dislocation, rising inequality, and political violence. Whether or not the Cuban state will be able to hold back the worst scenarios we have 
witnessed in other places remains to be seen. Why this is so, in the Cuban context, is an open and important question.

\section{References}

Associated Press. 2016. "Celebration, sorrow and slights greet news of Castro's death". Chronicle Herald. November 26. Accessed September 1, 2017. http://thechronicleherald.ca/world/1419135-celebration-sorrow-and-slightsgreet-news-of-castro's-death

Betancourt, Rafael. 2012. “Canadian Universities in Cuba.” Havana: Canadian Embassy in Cuba and CIDA.

Castro Ruz, Raúl. "Informe Central al VII Congreso del Partido Communista Cuba”. Cubadebate. April 17. Accessed August 21, 2017. http://www.cubadebate.cu/noticias/2016/04/17/informe-central-al-vii-congresodel-partido-comunista-cuba/\#.WbKy3a2ZP-Y

de los Angeles Torres, Maria. 2004. The Lost Apple: Operation Pedro Pan, Cuban Children in the US and the Promise of a Better Future. Boston: Beacon Press

Dubinsky, Karen, 2010. Babies Without Borders: Adoption and Child Migration Conflicts in the Americas Toronto: University of Toronto Press and New York: NYU Press.

- - . 2016. Cuba Beyond the Beach: Stories of Life in Havana. Toronto: Between the Lines.

- - - 2018. "Taking Generation NGO to Cuba: Reflections of a Teacher." In Other Diplomacies, Other Ties: Cuba and Canada in the Shadow of the US, edited by Luis René Fernández Tabío, Cynthia Wright, and Lana Wylie. Toronto: University of Toronto Press. 304-317.

Gandhi, Leela, 2006. Affective Communities: Anti Colonial Thought, Fin-de-Siecle Radicalism And the Politics of Friendship. Durham: Duke University Press.

Hayden, Tom. 2015. Listen, Yankee!: Why Cuba Matters. New York: Seven Stories. 
Judson, Fred, 1984. Cuba and the Revolutionary Myth: The Political Education of the Cuban Rebel Army, 1953-1963. Boulder: Westview Press.

Kirk, John M. and Peter McKenna. 1984. Canada-Cuba Relations: The Other Good Neighbour Policy. Gainesville: University Press of Florida.

Kirk, John M. 2015. Healthcare Without Borders: Understanding Cuban Medical Internationalism. Gainesville: University Press of Florida.

Kapcia, Antoni. 2008. “Does Cuba Fit Yet or Is It Still 'Exceptional'?”. Journal of Latin American Studies 40: 627-650.

Kapcia, Antoni. 2014. Leadership in the Cuban Revolution: The Unseen Story. London. Zed Books.

Klepak, Hal. 2005. Cuba's Military 1990-2005: Revolutionary Soldiers During CounterRevolutionary Times. New York: Palgrave.

Lundgren, Silje .2013. “Mami, you're so hot!' Negotiating hierarchies of masculinity through piropos in contemporary Havana" in Laura Alvarez Lopez et al. (eds.) Stockholm Review of Latin American Studies. 5-20.

Lutjens, Sheryl. 2014. "The Subject(s) of Academic and Cultural Exchange: Paradigms, Powers, and Possibilities." In Debating US-Cuban Relations: How Should We Now Play Ball?, edited by Jorge I. Dominguez, Rafael M. Hernández, and Lorena G. Barberia. New York: Routledge. 242-265.

Martínez Reinos, Milagros. 2017. "Academic Diplomacy: Cultural Exchange between Cuba and the United States." In Debating US-Cuban Relations: How Should We Now Play Ball?, edited by Jorge I. Dominguez, Rafael M. Hernández, and Lorena G. Barberia. New York: Routledge. 265-292.

Mills, C. Wright. 1960. Listen, Yankee: The Revolution in Cuba. New York: Ballantine.

Minh-ha, Trinh T. 1994. "Other Than Myself, My Other Self." In Travellers' Tales: narratives of home and displacement. George Robertson, Melinda Mash, Lisa Tcikner, John Bird, Barry Curtis and Tim Putnam. London-New York: Routledge. 8-25. 
Milke, Mark. 2016. "No, Fidel Castro did not deliver a better Cuba”. Globe and Mail. 29 November. Accessed September 1, 2017. https://beta.theglobeandmail.com/report-on-business/rob-commentary/no-fidelcastro-did-not-deliver-a-bettercuba/article33071380/?ref=http://www.theglobeandmail.com\&

Reuters. “A tyrant is dead': World leaders react to Fidel Castro's death”. New York Post. November 26. Accessed September 1, 2017. http://nypost.com/2016/11/26/atyrant-is-dead-world-leaders-react-to-fidel-castros-death/

Rojas, Rafael 2016. Fighting over Fidel: The New York Intellectuals and the Cuban Revolution. Princeton University Press.

Roediger, David. 2017. Class, Race, and Marxism. London: Verso.

Shome, Raka. 2009. "Post-Colonial Reflections on the 'Internationalization' of Cultural Studies." Cultural Studies 23 (5-6): 694-719.

Havana Times. 2017. "Cubans Must Now Go to Colombia to Apply to Immigrate to the USA." October 13. Accessed October 24, 2017. http://www.havanatimes.org/?p=127830

\footnotetext{
${ }^{1}$ Scholars who work on Cuban topics from Canada include Catherine Krull and Alexandrine BoudraultFournier (U Victoria), Jennifer Hosek and Susan Lord (Queen's), Gillian McGillivray (York), Lana Wylie (McMaster), Isaac Saney and Robert Huish (Dalhousie), Steven Kimber (University of King's College), Robert Whitney (University of New Brunswick), Robert Wright (Trent), Asa McKercher (RMC), Nicholas Balaisis (Waterloo), Archibald Ritter (Carleton), Don Munton (UNBC), Peter McKenna (UPEI), Alejandra Bronfman (UBC), Bernardo García Domínguez (U of T), Anton Allahar (University of Western Ontario).
} 